\title{
Humanist transfer of knowledge from foreign lands: modes of cognitive perception of the world among Florentine travelers to America between 1490 and 1530
}

\author{
Elisabeth Tiller $^{1}(1)$
}

Accepted: 5 September 2020 / Published online: 6 October 2020

(c) The Author(s) 2020

\begin{abstract}
In fifteenth and sixteenth century Italy, even before the beginning of the Age of Discovery, numerous (travel) reports were written by commercial travellers to Asian countries, soon followed by those to the Americas and the African coastal regions. In Florence, which was a Renaissance center of cultural innovation and a financially powerful hub for the exchange of knowledge, ideas, techniques and strategies, reports from Florentine travelers received particular attention. These epistemic materializations transformed, in primary emplotments, newfound material reality and real-space travel events into codified knowledge. Once they arrived Europe and circulated among European scholars, these cultural materials were then stored in further processes of knowledge materialization. Such secondary emplotments, from 1492 on, refer to a (geographically and historically) global framework that enforces the generation and classification of knowledge. For these purposes reports from travelling authors who already use a humanist standard of knowledge-like the erudite Florentine travelers Vespucci and Verrazzano-are able to deliver precious epistemic material, that, beyond the requirements of power politics, will contribute to re-coding not only the European perspective on the world, but especially the knowledge of the others.
\end{abstract}

Keywords Italian travel reports $\cdot$ Generating cultural knowledge $\cdot$ Humanism · Florence $\cdot$ Age of discovery $\cdot$ Vespucci $\cdot$ Verrazzano

Elisabeth Tiller

Elisabeth.Tiller@tu-dresden.de

1 Institute of Romance Studies, Faculty of Linguistics, Literature and Cultural Studies, TU

Dresden, 01062 Dresden, Germany 


\section{Florence as economic and epistemic center}

As a consequence of the international activities of the great Florentine banking and trading houses from the late mediaeval period onwards, the city of Florence, situated inland and without its own fleet, nevertheless produced a number of voyagers who wrote reports about their travels. Florentine travelogues can therefore serve in a special way as examples for the discourse on the world, in so far as geopolitical aspects of military action and conquest outside the Occident play a lesser role in inland Florence than for the maritime republic of Venice, which for centuries has been dependent on securing its own trade routes to Asia. Rather, the accumulation of 'cultural' world knowledge alongside military and geopolitical knowledge enjoys explicit political status in early sixteenth century Florence and is promoted accordingly. Correspondingly, Florentine travelers perceived the part of the world they visited economically and epistemically, a perspective that is revealed in their writings. It is obvious that Florentine travelogues were not only committed to the epistemic customs of their hometown, but also to writing routines from the Italian-speaking environment and, if necessary, from the Latin humanist discourse. Nevertheless, in what follows, I show how Florentine travel reports from this period differ from the other Italian travel reports of the time, in that, in an epistemically informed and knowledge-absorbing manner, they pay special attention to faraway things and circumstances. Italian, but especially Florentine travelogues of the period were satisfying a long-standing desire for knowledge about the foreign, which can only partly be delivered in reports about military circumstances or classifications of foreign customs and human habits. This desire also demanded material things that could be looked at and touched, and it required in particular the materialization of knowledge. The writers did this by means of the transcription of their observations according to canonized rules. But they also do this, beyond the realm of epistemic authority, as a re-evaluation of the things found by learned eyewitnessing, the confidence in one's own power of judgement: through experimental translation and location into the epistemic system, which in turn is thereby changed. Above all, however, at this point precisely, we can observe the entry of things into discourses and their transformational power in knowledge, their performative materialization-as something that plays an important role in the material culture studies as the 'stubbornness' (Hahn 2015) of (hitherto unknown) things (Berger 2019; Scholz and Vedder 2018; Genz and Gévaudan 2016; Kalthoff et al. 2016; 2015; Samida et al. 2014; Strässle et al. 2013; Coole and Frost 2010; Hicks and Beaudry 2010; Bracheret al. 2006; Tilley et.al. 2006; Appadurai 2005, 1986; Miller 2005; Mersch 2002; Ecker and Scholz 2000).

From the beginning of the fifteenth century, Florence developed into a dynamic center of Renaissance innovation in architecture, art and science-the establishment of design using linear perspective, the development of Florentine civic humanism and Neoplatonism, or the Medicis' art patronage, to mention just a few examples. In the fifteenth century the center and north of the Italian peninsula was a political patchwork of competing smaller and larger territories. 
Florence at this time was a financially powerful hub for the exchange of knowledge, ideas, techniques and strategies, developed in a lively urban culture and projected out into the world. Following the reception among the humanist scholars and mathematicians of Ptolemy's 'Geography' in the fifteenth century and the consequent strengthening of the cartographic school, the city also made significant contributions to the Age of Exploration. Of particular note is the role of the Florentine mathematician, physician and cartographer Paolo del Pozzo Toscanelli (1397-1482), whose maps and distance calculations were highly influential in Columbus's quest for a westward passage to China. Thus, in Florence a multi-faceted pool of knowledge was formed, constantly populated from numerous regions of the world, with polymorphic knowledge from travelers, art disciplines and powerhouses of ideas. This knowledge, epistemically organized, was subsequently released back into the world. The range of exploring foreign regions and generating knowledge was in the best sense a global one. It comes from an overstepping of boundaries and aims for the maximization of knowledge in an early capitalist sense.

As had been customary for centuries, at the beginning of the sixteenth century Italian merchants, scholars and navigators were travelling the world's seas and continents. The Age of Discovery can therefore also be described with reference to Italian, especially Florentine, protagonists: travelers who did so just before travel was transformed into an 'art' (Stagl 2002). Most wrote reports about socio-natural sites ${ }^{1}$ in distant regions of the world, which were later evaluated in their hometown and usually, particularly after the establishment of the printing press, also came to be known elsewhere. Some of these reports were distributed remarkably widely, such as the published letters of Amerigo Vespucci (1454-1512), which were circulating among intellectuals throughout Europe from 1503 onwards. Other travel accounts, such as those of the navigator Giovanni da Verrazzano (1485-1527) provided information to Florence, Lyon, Rome and the French royal court, which was passed on locally, but in the case of Verrazzano later acquired considerable cultural importance. In the 1520s Verrazzano wrote the first description of the North American coastal regions, which-in keeping with the humanist urban culture of the timecreated new standards for access to the world.

In what follows, I aim to accentuate the connection between the Florentine merchant culture in particular, the humanist knowledge cultivated in the city and the resulting discursification of encounters with the foreign (Waldenfels 1997, 2006), of cultural contact situations ${ }^{2}$ respectively confrontations in contact zones (Pratt 1991, 1992), especially by Florentine travelers (Masini and Gori 1998; Spallanzani 1997; Pagden 1993). The aim is to show how the specific perspective created by Italian actors socialized in an early capitalist urban environment has the effect of subjecting

\footnotetext{
1 On the concept of a "socio-natural site," the biophysical arrangement of settlements in an environment, as socially appropriated spaces and developed natural landscapes, cf. Knoll (2013, pp. 18-20).

2 Bitterli (1992) distinguishes three types of cultural contact that are relevant in the context of the discovery and conquest of the New World: cultural encounter, cultural collision and cultural relationship, which differ with regards to intensity, duration and potential for violence.
} 
the material found in the New World, and the manner of observing that material, to a process of discursive materialization. Due to the asynchronicity of cultural development, this perspective can be distinguished from other contemporary practices in Europe.

For this purpose, it is necessary to identify a mode of cognitive selection and interpretation of cultural transfer that produces 'emplotments' (Hayden White) that fit into the narrational conventions of a regional interpreting community. In this initial phase of the discursive interpretation of the New World, observed objects were transformed into classified knowledge content following criteria that varied from region to region. Non-simultaneity determines the selection, arrangement and materialization of knowledge. Relating to this, it is crucial to be aware that the epistemic record arriving in Italy from the thirteenth century on was based on reports from the Middle and Far East, which were frequently written from a mercantile point of view and thus created a thoroughly varied image of Asia. Over the course of the centuries, reports from Italian travelers who had often spent decades in the Far East, became increasingly detailed, saturated with information: (self) critical works often of a high literary standard. Authors like Giovanni da Pian del Carpini, Marco Polo, Odorico da Pordenone, Giovanni Marignolli, Francesco Balducci Pegolotti, Niccolò de' Conti, Iosafa Barbaro, and others reported on their own or other's time in the East, thereby establishing conventions that, in the fifteenth century, were combined with new humanist standards of generating, encoding and classifying knowledge. In this way, they preform reports of the new found land in the West that began to appear in 1492. The linguistic conditions of these materializations, as a part of the local conventions regarding the interpretation of the world, constitute at least the imagery of the discoveries in the West.

\section{Materiality and cultural contact situations}

The transformation of material reality into knowledge in the conditions of the Age of Discovery was conducted through media that, at the turn of the fifteenth to the sixteenth century, were subject to fundamental change. The European establishment of a printing culture created media conditions in which it was possible, for the first time, to reach a mass audience that was able to access written and/or iconographic contents made available on convenient, portable and reproducible media. Increasingly literate sections of the population could now participate in the circulation of knowledge, previously the reserve of a small élite. Travel reports which named, described and interpreted observations, thus integrating them into established contexts of meaning using conventional linguistic or iconological codes, therefore adapted ever more specifically to the new media environment that was developing during this period.

Furthermore, travel was per se very closely associated with material things (Bracher et al. 2006), such as the physical characteristics of the territory passed through or the means of transport used. The material contexts of day-to-day life while travelling compelled the traveler and explorer to constantly engage in new interactions with the environment. Travel was enriched by objects collected in the 
course of the journey. In addition, by this time actors making observations in distant or previously unknown parts of the world were benefiting from sense-enhancing technology. They used nautical and astronomical instruments, optical aids, and other technical devices to conduct a wide variety of activities, such as making records, production and reproduction, as well as using books and maps to assist them in the perception of the world they traversed. Finally, the reports of travelers and conquerors were recorded on material carrier media (books, letters, sketchbooks etc.). Here we find material, media-related, epistemic and artistic interactions generating sense in numerous ways: in a combination of linguistic signs or syntactically arranged linguistic material, writing instruments and carrier media, writing corpuses and printing presses which put the text onto the carrier medium (Kleinschmidt 2013); and, of course, like before the Gutenberg leap, the practice of reading important documents before a selected audience continued to ensure the oral circulation of information.

In order to determine these dynamics between material, materiality, knowledge and language/image in the relevant context, a distinction must be drawn between various categories of materials: namely, matter as materials whose physical qualities are only invoked here in a background role: as references to the form, value or prospective benefit of the materials described by the "discoverers"; material as perceptively selected materials, i.e. material that has been taken from its previous environment, from the primary material arrangement (Knoll 2013, pp. 98-103), and documented with specific interest and classified as "working material" for the (comparative) generation of meaning, the coining of terms and their transformation into knowledge ${ }^{3}$; and finally materiality, as the effect of the interaction of linguistic and/ or iconological discursification, material and media phenomena, which ultimately determines the "value" of the newly contextualized object of perception. Matter, material and materiality thus belong to different epistemic dimensions and also to successive time periods, making it possible to describe their respective status in a differentiated way.

In the case of the extremely concentrated cultural contact situations in both the Americas between 1492 and 1540, three spheres can be distinguished, each associated with the actions of individuals and "changes of location." (1) The sphere designated events in real space, (2) The sphere of the transfer of (tangible and intangible) material, and 3. The sphere of materialization through knowledge generation, which is usually associated with objects brought from the places concerned, as well as written reports or iconographical records. The sphere of events in real space encompasses the voyages of discovery conducted during this period by European actors who simultaneously functioned as human carrier media for Western knowledge and the corresponding cultural techniques. These voyages usually followed a

\footnotetext{
${ }^{3}$ On the discursive status of material cf. also Strässle (2013, p. 14): "However, it is of vital importance to see that material does not presuppose the existence of a given, irreducible 'starting substance' which may be grasped in a pre-discursive or pre-formative manner, but that the materials first have to be produced in the aesthetics and semantics attributable to them in a process of artistic production-i.e. in media, cultural and symbolic processes of constitution. The term 'material' thus refers not so much to the starting substance but rather to the product of artistic modelling and presentation, and it is only accessible to analysis in its respective media, cultural and symbolic presence."
} 
precise purposive rationality which is determined by domestic power relations or business interests. Cultural contact situations of the explorers and conquerors were often combined with the act of taking things away, and they left tangible and intangible imprints on the space, the memory, or the bodies of the human media carriers on both sides, i.e. the European travelers and the indigenous actors (who also initiated meaning-generating epistemic processes and create media representations).

The sphere of the transfer of (tangible and intangible) material means the spatial transfer of materials to and from the geographical area(s) touched by European actors. This material encompasses (medialized or memorized) observations, things (occasionally even animals and humans), foodstuffs, technology, images, viruses and bacteria, drawings and cartographical records, memoirs etc. Hence, exchange took place with indigenous groups which functioned in both directions and would bring about cultural and epistemic effects on both sides. This material is generally interpreted, in a primary emplotment, by the European actors themselves and is, by means of a process of cultural translation (Bhabha 1994), thus subjected to an initial narrative arrangement. A characteristic of this primary transfer is temporal and spatial distance from the events, enabling reflection and rational textualisation. Thus, this complex is characterized by the decontextualization of the things and experiences which have been taken from their former environment and transferred into European contexts.

The third sphere involves the process of materialization through knowledge generation, i.e. the process of integrating the material into existing knowledge categories or the expansion of existing discourses through material which was adapted to the linguistic-structural register, or which expanded it or brought about shifts in it. Things, observations and experiences that were authentically identified as belonging to the New World through eye-witness accounts were thus subjected in Europe to a secondary emplotment, in which the existing interpretations were varied, stabilized or rejected, and were thus transformed into facts which can be taken up by the hegemonial knowledge formations as evidence. The selected material was discursively transformed, being organized in collections or archives, i.e. in secondary material arrangements, and it was intermaterially re-contextualized. ${ }^{4}$ It was modified, accelerated and devalorized for the purpose of strategic knowledge management; in short, it is materialized as part of the European knowledge system and thus opened up to institutionalization. These epistemic materializations, the most evident expression of secondary cultural contextualization, i.e. their Europeanisation, ultimately reverberate to affect processes of social exchange. They confirm patterns of identity and otherness and in turn shape actions and acts of perception and interpretation, which are acted out in cultural contact situations in non-European cultural

\footnotetext{
${ }^{4}$ On this subject cf. Mersch (2013): "In addition, there is the further difficulty that 'materialities' can only be spoken of in the plural. Just as there are no isolated signs which can only be described once and for all, the semiosis always being located in the complexity of a transition or interlinkage, there are also no isolated materialities; rather, they are always found in relationships of tension, in a multi-faceted dialogue, an 'interlude', in order to open up a space of energies and lines of force with multiple resistance. Hence, it could be posited that only 'inter-materialities' exist.” (p. 29)
} 
environments, specifically in the process of the conquest and colonization of the two Americas.

Between the three said spheres, there is thus constant circulation of (old and new) materials and interpretations, which participate fluidly in the process of materialization. In the course of the synchronous and diachronous transfer processes within a global framework, both the materials and their interpretations undergo new transformations as a result of the ceaseless cultural encoding processes. In turn, these contingent meanings influence performatively future transfer processes and contact situations. After being integrated into the discursive meaning system, matter or material is thus highly productive.

\section{Florentine travelers to America and their representations of the Americas}

\section{Merchants and bankers}

The expansion of western civilization as a result of the numerous discoveries and voyages of exploration was pushed ahead by the Iberian seafaring nations, Portugal and Spain, who divided the world up between them as early as 1494, in the Treaty of Tordesillas. This was a challenge to the interests of the English and French, and later the Dutch, who also sought to take part in the geopolitical scramble for territory. This European competition for new lands was based on a combination of a capitalist pursuit of profits, a desire for military conquest and a sense of obligation to spread Christianity, on the one hand, and a systematic drive to acquire knowledge, on the other, creating a need to accommodate various strategies.

Thanks to the development of humanism, by about 1500 a new knowledge standard had been established on the Italian peninsula, something which was per se an effect of cultural transfer: namely, the reception and systematization of ancient classical knowledge and its syncretistic amalgamation with cultural conventions carried over from the Middle Ages. The resulting episteme, the Renaissance organization of knowledge-which was also associated with new artistic techniques, such as linear perspective in architecture and the visual arts, the new leading science of mathematics as well as the innovations in philosophy, medicine, astronomy, and cartography inspired by classical antiquity-naturally aspired towards expansion. This meant transfer processes, it meant that existing knowledge and modes of generating knowledge had been constantly expanded. Finally, the heuristic systematization of the augmented knowledge privileged visual perception (and its iconographical representation) as well as the critical viewing of traditional stocks of knowledge. Humanist scholarship, which in the cities of central and northern Italy was already clearly differentiated by the turn of the sixteenth century, combined with artistic and architectural developments to form a new type of culture, which was initially received somewhat hesitantly in other regions of Europe. Thus, Italian humanism as the knowledge standard came to be broadly known in the rest of Europe at around the same time as Renaissance art and literature, as well as the reports of the explorers and travelers to the New World. 
In Italy itself, Italian travel reports mainly from the Asian region, which already applied the principles of humanist epistemology, were being widely read. Geopolitical interests on the part of Italian territories (apart from the Spanish kingdoms in southern Italy), however, are almost non-existent-with the exception of late attempts by the Republic of Venice to defend its power and trading interests by preserving its remaining Mediterranean possessions and protecting its Far Eastern markets from Arab and Portuguese competition. Florentine trading houses and/or banks had long before secured a key position for themselves in competition with Venice, not only on the European financial market but also on the expanding global trading routes, which enabled them to reposition themselves economically in response to Spanish and Portuguese voyages of discovery (Guidi Bruscoli 2014). Hence, Florentine banks and trading posts in Spain, Portugal and France provided financial backing for Spanish, Portuguese and French ocean-going expeditions and sent their representatives along with them-and these sent detailed reports back to Florence. The reports were written in a stylish, rational, systematic and scholarly manner, as practical sources of information, yet at the same time provided entertaining narratives about the dangers encountered on their journeys.

These primary emplotments written by Tuscan bankers, merchants and seafarers are also characterized by a genre-dependent intertextuality which had developed over centuries. They drew on numerous Italian travel accounts from the midthirteenth century onwards, concerning diplomatic journeys or trading expeditions, mostly to the Far East. Apart from the political, military and mercantile information that was of primary interest to the Florentine banks and trading houses, these travel accounts contain various observations about the foreign lands visited. There are reports relating to natural history-flora, fauna and geomorphology, including notes on the climate and on soil quality and natural resources-attentive observations of foreign customs, foreign cities, transport routes and food, technology and arts, rituals, aesthetic concepts, conventions regarding the interpretation of the world, as well as religious practices. This recording tradition of Italian travelers, which developed over centuries, is thus a legacy of the notarial-documentary culture of civic life in central and northern Italy, which evolved from the medieval period onwards. Florence as a center of humanist studies and hence of new cognitive procedures of systematic interpretation of the world very clearly adopted a key epistemic propagatory function in the fifteenth and early sixteenth century, transferring the material into secondary emplotments and materializing it as knowledge- a special role characterized by the republican civic humanism, the mathematical school, Neo-Platonism, literature and the study of Antiquity as cultivated in the city in the fifteenth century.

The relevance of the reports and objects from distant lands, i.e. the materials brought from the Far East and the New World-not only for traders, bankers and powers-that-be but also for humanist scholars, artists and educated laymen-was also soon sought after all over Europe. As early as 1507, the first collection of travel reports by Fracanzio da Montalboddo (Scruzzi 2010) was printed in Vicenza by Henrico Vicentino \& Enrico Ca' Zeno under the title Paesi novamente retrovati. ${ }^{5}$

\footnotetext{
5 (https://diglib.hab.de/edoc/ed000145/start.htm).
} 
It quickly went through fifteen editions and was translated into four languages. The northern Italian figure Peter Martyr, whose real name was Pietro Martire d'Anghiera (1457-1526), collected travel accounts concerning the explorations of Central and South America. After printing unauthorized Italian volgare compilations in 1504 and 1507 (in Venice) and Latin editions in 1508 and 1511, he published the work De orbe novo Decades in Spain (Alcalá de Henares) between 1516 and 1530. ${ }^{6}$ These were syntheses of discoveries made in Central and South America, including two reports about Columbus he had produced for the Roman Cardinal Ascanio Sforza in the early $1490 \mathrm{~s}$.

Finally, the Venetian Giovanni Battista Ramusio (1485-1557) was the first to compile reports by various explorers according to geographical regions (Asia, America, Africa) under the title Delle navigationi e viaggi, published in Venice (Giunti) in three weighty volumes between 1550 and $1559 .{ }^{7}$ Ramusio's compilations (Ramusio 1978-1988), one of the most comprehensive editorial undertakings of the sixteenth century (Storz 2009; Romanini 2007; Albertan-Coppola and GomezGéraud 1990; Milanesi 1982), contain Spanish, Portuguese and French explorers' reports translated into volgare, as well as all the Italian travel accounts Ramusio was able to get hold of since those of Marco Polo. The presentation of these travel accounts in the common language of the people meant an exponential increase in the potential readership. Ramusio's publication, which naturally included the reports by Vespucci and Verrazzano and many of those mentioned below, was then followed by the first English-language compilations of travel reports, produced by Richard Hakluyts under the titles Diuers Voyages touching the Discouerie of America, and the Ilands adiacent vnto the same (1582) and The Principall Nauigations, Voiages and Discoueries of the English Nation (1589). These sixteenth-century publications, which consisted of summaries or revised original reports, provided a large pool of information which together gave the readership primary material as well as contextual information and commentary. Another significant aspect is the handy, portable format which made the condensed experience of scholars available for domestic use. Thus, from the mid-sixteenth century onwards, information about the New World quite literally entered those European households whose level of education, curiosity and financial circumstances were conducive to such reading materials.

At the turn of the sixteenth century, when primary emplotments of the journeys of discovery heading for the New World were still rare and read mainly by merchants (Michael 2002), scholars and directly addressed rulers, there were also Florentine correspondents and travelers from other Italian territories who were conducting business all over the world. Most of their reports were written in volgare. In 1504 the Florentine merchant Giovanni da Empoli (Spallanzani 1999, 1997; Ramusio 1978, vol. 1), along with 20 other Italian traders, travelled to India on ships belonging to a Portuguese fleet chartered by the Florentine trading house Marchionni (Guidi Bruscoli 2014). In a letter to his father written in 1504, Empoli reported this voyage to India, and years later he wrote another report about a journey to the

\footnotetext{
6 (https://archive.org/details/deorbenouopetrim00angh/page/n5/mode/2up).

7 (https://digi.ub.uni-heidelberg.de/diglit/ramusio1554bd1/0007).
} 
Malayan archipelago (1510-1514). Empoli's letters circulated in Florence, particularly because he wrote in a highly vivid way about the dangers of the voyages. In Lisbon, where a large group of Florentine traders were financing Portuguese voyages of discovery around the turn of the century, the Florentine merchant Girolamo Sernigi (Spallanzani 1997), scion of a major Florentine trading house, compiled a report on the latest Portuguese undertakings, including those of Vasco da Gama. The reports written by Sernigi also circulated in Florence. The Florentine scholar and cosmographer Andrea Corsali (Ramusio 1979, vol. 2), who was closely associated with the House of Medici, travelled the Indian Ocean on Portuguese ships between 1515 and 1518, and reported on India and the Arabian regions in letters to Giuliano as well as Lorenzo di Piero de' Medici; letters which were immediately printed in 1516 and 1518. However, other Italian travelers also produced descriptions of major voyages during this period. Antonio Pigafetta, for example, a cartographer from Vicenza, published his report about the first circumnavigations of the world under Magellan (1519-1522), after returning in 1525 as one of the few survivors (Ramusio 1979, vol. 2). Another example is the Bolognese adventurer Lodovico de Varthema (Rubiés 2000, pp. 125-163; Reichert 2000, 1996), who submitted his Itinerario (Ramusio 1978, vol. 1), a detailed, yet exciting and entertaining report about his eight-year sojourn in the Far East, for publication in Rome in 1510, and this work went to more than 50 editions: clearly, the interest of the public, in the face of exponentially growing tales of the unknown territories, was rapidly increasing. A market for printed books was emerging within a very short time; it quickly developed precise expectations and thereby created new genres, such as literary travelogues, which would become successful in the coming centuries.

At the beginning of the sixteenth century, however, these narrations, which were dutifully filled with an abundance of information about foreign lands, were still usually transmitted in the form of letters (Michael 2002). The letter as a handwritten medium, like other manuscripts, continues to serve until the beginning of the sixteenth century, as Michael Giesecke points out (2006, 42-50), as a medium of information, not as a medium of communication as in the advanced culture of printing. Letters as individual scriptographic media transport precise information for their cultural context, which may only be transformed later into typographic and thus social communication media in the present sense (Giesecke 2006, 42; Giesecke 1991). Nevertheless, the letter has always fulfilled communicative roles for specific groups and institutions, which are connected to each other via the respective messenger system. Messengers deliver documents that tell of experiences and provide information that is delivered to one or, through multiple dedications, to many addressees in order to keep the content exclusive or open it to a specific audience. Letters were passed on like an exchange of gifts, or read-as a solemn stagingin society, for example in churches and universities, at imperial diets, councils or courtly feasts. The audiences thus constituted were nevertheless small in number. It is only with the publication in print, as slowly became common practice from the beginning of the sixteenth century, that the new reading public can no longer be surveyed.

The letter as traditional medium for informational exchange - though at this point in time, it also had long since become a privileged and linguistically refined carrier 
medium for humanist debate within the European scholarly community-therefore served as the preferred means of communication. It was a dynamic carrier medium in which the seafarers and observers, who were required to report regularly to the sponsors of the undertakings, could circulate their travel reports and statements of account. The discovery and exploration of the Americas after 1493, since Columbus's letter to the court treasurer Luis de Santangel, was continually accompanied by reports in the form of letters. It was in this form that Columbus documented his first voyage and the discovery of what he presumed to be Asian islands. ${ }^{8}$ These were followed by the letter by Pêro Vaz de Caminha reporting on Cabral's discovery of the Brazilian coast in 1500, Amerigo Vespucci's letters about the exploration of the Brazilian coast and thus of a new continent, and finally by the five letters written by Hernán Cortés concerning the conquest of Mexico, which were sent to Spain between 1519 and 1526 and partially published there. We find ourselves on the threshold between a scriptographic report in the form of a traditional letter for a relatively small group of initiates, who are allowed to participate in the exclusive information, and the typographical distribution of first-hand information, which, hardly available in printed form for a large reading public, was to shape the interpretations and images within the European population through its discursive form. The content and form of these cartas de relación/cartas relatorias (Stoll 1997) concerning the early years of discoveries in the Americas not only had an influence on the image of the Americas and the treatment of the foreign and the new, the Other in the west. They were also the first sources to introduce the existence of the New World into European discourse formations and, through their compact narrative structure and their extensive circulation, to operationalize its entry into the western system of knowledge. The motifs used in the comparisons and hierarchies set out there, and the narrations and toponymizations used, were to shape the image of the New World for a long time to come. From 1530 onwards, these reports were finally supplemented by cartas geográficas sent to the American territories by the Spanish royal house, thus gradually supplementing the primary information provided in the cartas de relación in a systematic and institutionally established way. They took the form of questionnaires submitted to the Spanish colonial authorities posted there, and were used for decades as sources of information. The materialization of knowledge thus took place at different levels for increasingly differentiated purposes, each of which, progressing, applied or generated different codes.

The descriptions written by Italian reporters conform to rules that had evolved in Renaissance humanist culture, which in the early sixteenth century diverged from Spanish and Portuguese conventions. On the one hand, they were committed to a genre-typical rhetorical code; but at the same time, following the humanist requirement of variatio, they break with the conventions of the (travel) report, using the literary style of scholarly epistolary culture. The primary textualisation processes of the Florentine reporters in particular nevertheless take account of pragmatic practices in the interpretation of the world, which combined mercantile interests and

\footnotetext{
${ }^{8}$ By 1522, twenty editions of his Epistola de insulis nuper inventis had been published in Latin, Italian, Spanish, German and English (Michael 2002).
} 
secularized civic culture to emphasize a strategic perspective related to everyday life. In this way, not only are different registers hybridised, but also an interest was thus cultivated in the heterogeneity of foreign cultures that is based on respect and promotes business, along with recognition that - as was evident at least since the travels of the Venetian Marco Polo-these cultures might even be superior to one's own.

In the early sixteenth century Italian composers of such reports were usually educated readers of travel accounts who had also enjoyed a sound humanist education and therefore were in possession of intertextual and sometimes literary skills. Their descriptions are evidence of the eyewitnesses' desire to observe and the hermeneutic abilities of a humanist interpretive community, which simultaneously shaped the expectations of the target readership. Regarding the textualization and the epistemic classification of new areas of knowledge, the early Italian evidential texts from the Age of Discovery are thus in a cognitively and aesthetically privileged position. These texts are set apart from those of other European interpretive communities of the period. It is therefore no coincidence that some of these emplotments were distributed throughout Europe and had a formative influence on the subsequent modelling of the modern world-as products of interpretation on a growing market of competing materializations of knowledge, which, as representations of distant worlds, struggled for hegemonic positions. Here begins the formation of a notion of the world as a circulation complex of communications, goods, people and ideas in an secular space, based on exchanges.

\section{Amerigo Vespucci (1454-1512)}

The most influential Florentine reports produced in the early sixteenth century were undoubtedly those of Amerigo Vespucci (Omodeo 2017; Pinto et al. 2014; Azzari and Rombai 2013; D’Ascenzo 2004; Heijkant 2003; Briesemeister 2002; Wallisch 2002; Ramusio 1978, vol. 1). Out of a total of six letters written by Vespucci to Lorenzo di Pierfrancesco de' Medici and Piero Soderini-describing his four voyages along the Central American and Brazilian coasts-two were circulating among educated humanist scholars in Europe from 1503 onwards. These versions were specifically prepared for publication and were printed in Latin. Vespucci, the son of a Florentine notary, had been employed in the bank run by Lorenzo di Pierfrancesco de' Medici since 1482 and had represented the company's interests in Seville since 1491. Following the death of the head of the branch, Giannotto Berardi, in 1495, he was given sole responsibility as its manager. In addition, Berardi-also a ship-owner-and Vespucci had also collaborated with Columbus in founding a finance company that helped finance the Admiral's first westward voyage: thus, the Florentine banks and commercial houses, notably the Medici, were fundamentally involved in the westward voyages of discovery from the very outset. As a result, between 1497 and 1505, Vespucci was able to personally participate in four voyages of exploration as an observer and navigator. The first two were conducted under the Spanish flag and the last two in the service of the Portuguese, who succeeded in 
headhunting the financier and cartographer despite the security concerns that usually predominated.

Vespucci's reports written in the form of letters in volgare between 1500 and 1504 and addressed to Lorenzo di Pierfrancesco de' Medici, dating from July 1500, June 1501, autumn 1502 (the "Bartolozzi Letter") and the so-called Ridolfi Fragment from early 1503, were not intended for publication (Wallisch 2002). The situation is different as regards the Mundus novus letter, also addressed to Lorenzo di Pierfrancesco de' Medici, which was prepared for publication. It was written in volgare between September 1502 and May 1503 and provides a summary of the third voyage in which Vespucci took part. It was encoded specifically for an audience of scholars in Europe, where the published Latin version quickly evoked considerable excitement. In addition, there was a letter to Piero Soderini, the new Gonfaloniere of the Republic of Florence, which is dated 4 September 1504. It summarized all four of Vespucci's voyages in volgare and was circulated in Italian printed versions from 1504 onwards. This letter also acquired further importance through a Latin translation which was included under the title Quattuor Navigationes in Martin Waldseemüller's Cosmographiae introductio (Saint-Dié 1507). ${ }^{9}$ The two quickly printed reports resulted in numerous translations into European languages and new editions, as well as promptly created and printed woodcuts illustrating Vespuccis 'sensations' (Obermeier 2002). The Rostock print of Mundus novus from 1505, for example, purchased by the Rostock University Library in 2019, is the only edition in folio format (all other editions are smaller, i.e. in octavo or quarto), which contains several illustrations, including a hand-colored world map after Ptolemy. ${ }^{10}$

Vespucci's epistolary reports are all highly detailed, containing vivid accounts of the travel route and summarizing all the most important information about the newly discovered lands in the west in a discursively penetrating, rhetorically wellstructured and literary style. They generate primary emplotments and provide material that is masterfully presented, both linguistically and semantically. The first person narrator confidently positions himself in the text as a judging observer of the things that are documented and repeatedly makes comparisons with European circumstances or refers to the Bible or classical authors, i.e. traditional intellectual authorities such as Aristotle, Plato or Pliny, to classical art and Renaissance art theory. Vespucci also throws in literary quotations which, as a true Florentine, he mostly takes from the writings of Dante and Petrarch. He occasionally describes the people encountered and their conventions with respectful and appreciative interest; elsewhere he emphasizes the exotic and sensational, using the topos of cannibalism to illustrate the irreducibly Other, an established practice in Italian travel writing since the time of Marco Polo. He documents the material culture and environments of the Brazilian coast as well as the biophysical composition of indigenous groups; he describes the abundant richness of the flora and fauna, provides extensive astronomical material and calculations for determining the positions of heavenly bodies. Vespucci thus shows himself to be an all-round accomplished rhetorician who was

\footnotetext{
9 (https://epub.ub.uni-muenchen.de/11046/1/Cim._74.pdf).

10 https://purl.uni-rostock.de/rosdok/ppn1666749583.
} 
ideally equipped, according to humanist criteria, to report skillfully on his own experiences whilst simultaneously recording knowledge. Vespucci's first person narrator makes decidedly moral judgments and in doing so follows established discourse traditions, yet he does not project the image of a bigot. The author, whose target audience consists of European scholars, notes inexplicable things and remarks on differences; he delights in making interpretations, attributions, projections and predictions. He provides nautical and astronomical observations, distances and measurements; he is a veritable cosmographer who opens a new discourse with a fresh configuration of the world. Thus, in Vespucci's reports different discourse traditions and schemes of interpretation coexist, these being expressed partly in traditionalist and partly in epistemically modern ways. These discourse strategies are consolidated with the arrangement of the new, the hitherto unknown matter, the things and fields of phenomena which per se demand new interpretations. The first person narrator can then substantiate these with his own observations, with the empirical facts of the matter.

Vespucci was motivated by that Early Modern curiositas (D'Ascenzo 2004; Daston 2002; Kiening 2002; Krüger 2002; Stagl 2002) that, faced with new objects of knowledge and opportunities to acquire knowledge, cultivated an intellectual fascination for the unknown, for comparisons between familiar and foreign worlds, for reflection on the existing order, for the transcultural and liminal-thus anticipating modern knowledge cultures and their heuristic techniques. The view of curiositas as concupiscentia oculorum ('lust of the eyes'), an inquisitiveness disavowed as a vice since the time of Saint Augustine, assumed completely new tones, at least in the writings of some reporters, in the context of the exploration of the New World. Interest-driven by cognitive desire but rationally controlled-in seeing and interpreting newly discovered things was a necessary prerequisite for coping with the numerous phenomena pouring into the Christian civilization of Europe in the Early Modern era.

Vespucci distinguished himself in this regard at an early stage. A major factor in the huge success of the Mundus novus letter was undoubtedly the introductory passage, which explicitly rejected former authorities and proclaimed-with exceptional self-assurance and with calculated rhetorical technique-a confident conclusion. The sections of coast visited by the first person narrator were not, as Columbus had still claimed, Asiatic islands but were instead parts of a previously unknown, extremely rich and densely populated continent:

On a former occasion I wrote to you at some length concerning my return from those new regions which we found and explored with the fleet, at the cost, and by the command of this Most Serene King of Portugal. And these we may rightly call a new world. Because our ancestors had no knowledge of them, and it will be a matter wholly new to all those who hear about them. For this transcends the view held by our ancients, inasmuch as most of them hold that there is no continent to the south beyond the equator, but only the sea which they named the Atlantic; and if some of them did aver that a continent there was, they denied with abundant argument that it was a habitable land. But that this their opinion is false and utterly opposed to the 
truth, this my last voyage has made manifest; for in those southern parts I have found a continent more densely peopled and abounding in animals than our Europe or Asia or Africa, and, in addition, a climate milder and more delightful than in any other region known to us, as you shall learn in the following account wherein we shall set succinctly down only capital matters and the things more worthy of comment and memory seen or heard by me in this new world, as will appear below. (Vespucci 1916, p. 1)

In this respect, Vespucci's report reflects the secular and spatially modulated commercial standards that were cultivated in Florence and other Italian trading cities. At the same time, they illustrate the humanist paradigm shift in the course of which - on the basis of explicitly subjective experiential knowledgethe deconstruction of the authority of the ancients and of scholastic thought had taken place since the late fifteenth century. Nevertheless, Vespucci was sufficiently skilled in the use of established discourse conventions, which are highly conducive to the necessary cultural translation as a fitting of the reported things into established discourses of knowledge.

Vespucci's two reports, immediately printed and circulated throughout Europe, summarize the most important information about the New World in a compact and discursively impressive form. Their points of divergence from established geographical doctrines are stated openly in the text and are rhetorically functionalized. Vespucci's writings thus provided the incipient discovery discourse with an underlying academic basal code which used rhetorical procedures, conceptions and images that were standard in the humanistically-oriented travel writing of Italy. As a result, the continent hypothesis that it popularized quickly spread. This process was assisted by the German cartographer Martin Waldseemüller, one of the first to adopt Vespucci's hypothesis in his Cosmographiae introductio, published in 1507. This includes, for one thing, the publication of the Latin version of the letter to Soderini as an outline of Vespucci's voyages. For another, however, their permanent cartographic materialization comes to the fore. On his Cosmographia world map, Waldseemüller gives priority to Vespucci's achievements in the transfer of knowledge over Columbus's original discovery by naming this continent after him: the New World became America.

Thus, in the case of Amerigo Vespucci, the materialization of knowledge took place in several stages of action and media transfer, which can be traced as a comprehensible process. Vespucci's discursification of matter explored in his presence generates newly compiled and in part newly conceived knowledge. The comprehensive and resounding reception of this knowledge is in turn due to the knowledge potential opened up, the rhetorical skill of the author and the media contexts of the period around 1500. What Vespucci's knowledge arrangement and transfer, inspired by the Florentine environment, produced in cultural terms is not only_as can be read in Joachim Michael-a New World in the west but also a complete renovatio of the European view of the world. It is a repositioning which Vespucci himself consciously presents as revolutionary in his printed publication (Kiening 2007; Michael 2002). 


\section{Seafarers: Giovanni da Verrazzano (1485-1527)}

Around the turn of the fifteenth to the sixteenth century European exploration of the world's oceans benefited not only from Italian financial backing but also from some outstanding seafarers: Cristoforo Colombo (1451-1506) of Genoa sailed westward in the service of the Spanish crown under the name Almirante Colón and discovered the New World. John Cabot (c.1450-1498), the first traveler to America under an English commission, who set out in search of the North-West Passage, was previously known as Giovanni Caboto and was a former citizen of Venice. Finally, the Florentine seafarer Giovanni da Verrazzano (1485-1527) was commissioned in the $1520 \mathrm{~s}$ by the French King François I to find a navigable route to China. All three sailed on behalf of major European powers whose geopolitical ambitions were of decisive importance in driving forward the European opening up of the world. Just as Columbus's voyage had had the financial support of Vespucci, Berardi and the Medici Bank, Verrazzano's ships for his first westward voyage were financed by the Florentine merchants in Lyon, and the Rucellai banking house. The first voyage, undertaken under a privilege issued by the French King in 1524, took Verrazzano along the North American coast from Florida as far as Nova Scotia; the second voyage in 1526/27 passed the Cape of Good Hope and Madagascar before visiting Mozambique and Brazil on the return journey. Giovanni da Verrazzano was part of a third expedition in 1528 and travelled as far as the Caribbean, where he was killed and allegedly eaten by natives on one of the islands of the Lesser Antilles (Tiller 2013; Ramusio 1988, vol. 6; Mollat Du Jourdin and Habert 1982; Morrison 1971; Wroth 1970).

Verrazzano's description of the first voyage, in a letter written in Italian to King François I dated 8 July 1524 (Verrazzano 1970; Tarrow 1970), was first received by two Florentine merchants in Lyon and to Bonacorso Rucellai in Rome, whose Florentine banking house had made the expedition possible. The report begins with the departure from Madeira on 17 January 1524 and ends with the voyagers' return to Dieppe in July of the same year. However, it was not printed: Verrazzano's account was read out and circulated in transcript form in Lyon, at the French royal court, in Florence and in Rome.

After a crossing lasting approximately 50 days, as shown by the events on this first Atlantic voyage by Verrazzano, the caravel Dauphine reached the North American coast near Cape Fear, before veering slightly southwards in search of a harbor and reaching northern Florida; it then sailed northwards up the whole coast as far as Cape Breton in modern Canada. Verrazzano's report has 32 pages and, in keeping with prototypes, it concentrates on landscapes and people, fauna and flora, soil quality, natural resources, anchoring places and weather conditions. He also attempted to discuss military, natural history and mercantile issues: again, he was motivated by a very pragmatic type of curiositas that caused him to systematically seek relevant information geared to the interests of the French royal house.

Unlike Columbus, Verrazzano's main priority was quite clearly the generation of knowledge, rather than the taking possession of territory and the prospect of riches. At any rate, in his account, which is clearly informed by his humanist upbringing, this Florentine seafarer from an aristocratic family was certainly able to give a 
convincing impression that he was motivated primarily by cognitive desire. Verrazzano selects information according to a pragmatically adapted form of presentation which makes use of literary models and displays extensive knowledge of European travel literature. Naturally, he frequently makes reference to his subjective experiential knowledge, using this as a means of authentication. The phrase "from what we could tell from observation" (Tarrow 1970, p. 134), which appears again and again in various forms, the expertise of the primary emplotment is concentrated somewhat more forcefully than had been the case twenty years earlier in the writings of Amerigo Vespucci.

The descriptions of the coastal inhabitants-unlike those in most cartas de relación-provide a surprisingly variable image of their behavior during cultural encounters, whose impact seems to be something of which the author is clearly aware. Their behavior ranges from immediate flight to planned attack, from a reserved welcome to a generous willingness to help the new arrivals. On the other hand, Verrazzano is even more interested than other contemporary authors in the physical characteristics of the indigenous groups, and he deliberately overdraws them for literary effect: he emphasizes their beauty and powerful build, their hairstyles and facial features, their eyes and gaze, tending towards aestheticized exaggeration. The descriptions of the physical characteristics of these newly encountered people sometimes include far-fetched comparisons. "Very like the manner of the ancients" (Tarrow 1970, p. 138) writes Verrazzano ebulliently when describing what he calls the most beautiful and friendly indigenous group they had met. For the Florentine navigator, the exalted model of classical antiquity set the standard as regards the aesthetics of the human body, a view which had been shaped by fifteenth-century writers on art theory and was based on the established canon of antique sculpture. In the process of cognitive transfer, the identification of Renaissance standards of beauty with the physical characteristics of American indigenous peoples motivated cultural projections which in the case of Verrazzano's allusion to classical ideals add to Columbus's earlier reference to the 'noble savage' a new, decidedly humanist and aestheticized component that in the sixteenth century, and particularly in this early phase, was certainly of an innovative character.

Verrazzano's description of the cultural exchanges he experienced were clearly intended to influence later cultural relations. Missionary aspects, however, are absent, and there is no attempt to relate what was observed to Christian universalism. Indeed, towards the end of his account Verrazzano draws a remarkable conclusion from the absence of religious practices, which he could not discern: although he assumes an a priori ignorance on the part of the indigenous groups, he states that, "We consider that they have no religion and that they live in absolute freedom" (Tarrow 1970, p. 141).

He can often find out nothing about everyday life, the reasons for this being stated as failure to make contact, inability to communicate or the short time spent on land. However, where possible, Verrazzano does report on the types of food eaten and the local dwellings, on the style of weapons or boats, and on social hierarchies. The parameters he uses for comparison are mostly the Orient or China, sometimes also classical antiquity or the Middle East. In this, Verrazzano does not differ in principle from the textualisation procedures used by Columbus or Cortés, who sought to 
transfer the already sedimented images of the familiar, mainly Ottoman or Moorish, 'other' to the new, more distant 'other' (Todorov 1982). However, Verrazzano employs a remarkable variety of comparisons and intersperses details taken from European travel literature that corroborate his observations. His descriptions of topographical peculiarities, on the other hand, are less refined. The differences compared with what is already known are so small that European images are sufficient to characterize them. North American landscapes are not portrayed by Verrazzano as strange or threatening, but rather as similar and controllable, and hence open to cultivation. For example, he proposes technology transfer in order to optimize the existing land use for such activities as viticulture on the model of his Tuscan homeland.

Nevertheless, Verrazzano makes abundant use of the privilege of the discoverer and gives toponymic names to the areas explored. He does this above all in the Codex Cellere, a transcript to which he adds handwritten remarks as marginal notes in which he gives names to locations (Wroth 1970, pp. 96-120). These toponymic names are usually encomiastic French-sounding toponyms ("Francesca," "Angoleme," "Vandoma," "Le III figlie di Navarra"), supplemented by Italianized names ("Selva di Lauri," "Campo di Cedri," "Annunciata," "Pallavisino"). The sections of coast explored were surveyed and cartographically recorded, although this was where Verrazzano's most serious error entered the European episteme-the very cartography of America. The lagoons behind the sandbanks at Cape Hatteras, now known as the Pamlico and Albemarle Sounds (Schwartz 2003, p. 46), were interpreted by Verrazzano as the Pacific Ocean, suggesting that the Atlantic and Pacific were separated only by a narrow land mass no more than six miles wide. In 1529 his cartographer and younger brother Girolamo Verrazzano, who probably already accompanied him on this first voyage, produced a world map (now held in the Biblioteca Vaticana) showing this land bridge in northern Florida, thus permanently materializing this misconception. However, this map was not the first cartographical expression of the information supplied by Verrazzano: The Genoese cartographer Vesconte de Maggiolo already represented this narrow land bridge on a map in 1527, showing that he was familiar with the travelers' or with Verrazzano's account (Schwartz 2003, pp. 53-54; Mollat Du Jourdin and Habert 1982, pp. 156-167; Wroth 1970, pp. 170-177). Verrazzano's misinterpretation was to leave its mark on international cartography for decades afterwards (Schwartz 2003; Mollat Du Jourdin and Habert 1982, pp. 168-201; Wroth 1970, pp. 178-216).

As in the case of Vespucci, with whose reports Verrazzano was familiar, the discursification of the experiential knowledge he had acquired led to the systematic revision of geographical standards humanist scholars had obtained from ancient sources ("which was unknown to the ancients"; Tarrow 1970, p. 142). In doing so, Verrazzano produces a long list of positioning data and calculations-and states that he was unable to fulfill his original intention of finding a sea route to China, although the classical authorities had asserted that such a route existed ("this was the opinion of all the ancients"; Tarrow 1970, p. 142). This assertion had now been proven false by "the moderns" (Tarrow 1970, p. 142): new land had been discovered that was unknown to the ancients-indeed, a whole continent with an expanse even greater than that of Europe, Africa or Asia. In this, Verrazzano was evidently following Vespucci: "Land has been found by modern man which was unknown to 
the ancients, another world with respect to the one they knew, which appears to be larger than our Europe, than Africa, and almost larger than Asia, if we estimate its size correctly" (Tarrow 1970, p. 142).

Verrazzano, whose text clearly demonstrates his awareness of living in a "new age," reinforces his hypotheses by referring to the latest Spanish and Portuguese discoveries. Thus, experiential knowledge becomes the ultimate proof, even beyond personal participation. "We have proven it by experience" (Tarrow 1970, p. 143) he writes towards the end of his account, which he self-confidently calls "our cosmography" (Tarrow 1970, p. 143). In this way, Verrazzano, like Vespucci, attests to that which, in terms of cultural history, marks out the humanist achievements of the period: namely, concentration on the empirical interpretation of found materials, a mathematically sound, secular, spatial hermeneutics based on experimentation and with relevance for everyday life, in contrast to the book knowledge of the ancient authorities. Hence, these works can be considered a prelude to the scientific revolution of the seventeenth century.

\section{Concluding remark}

Vespucci and Verrazzano were both educated members of the urban upper class with a background in literature, the arts, philosophy, mathematics and cartography, who had enjoyed an upbringing firmly in keeping with Florentine cultural standards, whose professions ensured their obligation to spatial pragmatism, and who produced model examples of a primary emplotment that is clearly humanistic in terms of both content and style. Both text strategies function with full awareness of the secular reorganization of knowledge about the world: with awareness of a dynamic, classically formed and rationally critical expertise and artistry that, during the fifteenth century, had established the transgression from conventions based on authorities as a modus operandi. In both authors, the discursive construction of America features actors who, in the staging of the text, do not primarily aim to subject, appropriate and exploit. Presented in a comparatively unideological way and corresponding perfectly to the demands of the medium, they reveal instead cognitive curiosity and obvious interest in the phenomena discovered, and these are condensed into discovery narratives whose appeal derives precisely from the combination of different perspectives and registers. Both narratives of the New World transversely preform modern knowledge, inasmuch as the classicist knowledge that refers to ancient standards is amalgamated with the experiences of the age of discovery, synchronously accumulated by contemporary actors, and with knowledge obtained in the Middle and Far East, of foreign Eastern cultures and the habitats of previous centuries. Vespucci and Verrazzano's culturally transverse primary emplotments transform and transfer the materiality of the New World, the primary material arrangement both had found in the Americas, into knowledge codified inter alia according to humanistic criteria. This then codified knowledge is ultimately reread, rearranged in secondary emplotments, augmented or reused in secondary materializations by European scholars-as a further part of the process of materialization through knowledge generation. The 
primary emplotments on foreign parts of the world do not only provide selective knowledge for the purposes of power politics, but also offer a variety of narrations of foreign environments - narrations which perfectly fulfill the new secular request for knowledge of a world that, in the age of discoveries and the first modern media revolution, was constantly gaining in complexity.

(Translation: Geraldine Schuckelt et al.)

Funding Open Access funding enabled and organized by Projekt DEAL.

Open Access This article is licensed under a Creative Commons Attribution 4.0 International License, which permits use, sharing, adaptation, distribution and reproduction in any medium or format, as long as you give appropriate credit to the original author(s) and the source, provide a link to the Creative Commons licence, and indicate if changes were made. The images or other third party material in this article are included in the article's Creative Commons licence, unless indicated otherwise in a credit line to the material. If material is not included in the article's Creative Commons licence and your intended use is not permitted by statutory regulation or exceeds the permitted use, you will need to obtain permission directly from the copyright holder. To view a copy of this licence, visit http://creativecommons.org/licen ses/by/4.0/.

\section{References}

Albertan-Coppola, S., \& Gomez-Géraud, M.-C. (1990). La collection des 'Navigationi e viaggi' (15501559) de Ramusio'. Revue des études italiennes, 36, 59-70.

Appadurai, A. (Ed.). (1986). The social life of things. Commodities in cultural perspective. Cambridge: Cambridge University Press.

Appadurai, A. (2005). Materiality in the future of anthropology. Commodification, 51, 55-62.

Azzari, M., \& Rombai, L. (Eds.). (2013). Amerigo Vespucci e i mercanti viaggiatori fiorentini del Cinquecento. Firenze: Firenze University Press.

Berger, C. (2019). Conceptualism and materiality. Matters of art and politics. Leiden: Brill.

Bhabha, H. (1994). The location of culture. London: Routledge.

Bitterli, U. (1992). Alte Welt - neue Welt: Formen des europäisch-überseeischen Kulturkontakts vom 15. bis zum 18. Jahrhundert. München: Beck.

Bracher, P., Hertweck, F., \& Schröder, S. (Eds.). (2006). Materialität auf Reisen. Zur kulturellen Transformation der Dinge. Berlin: LIT.

Briesemeister, D. (2002). Amerigo Vespuccis Briefe über die Neue Welt. In: S. Lang, J. Blaser \& W. Lustig (Eds.), ,Miradas entrecruzadas. “ Diskurse interkultureller Erfahrung und deren literarische Inszenierung (pp. 73-90). Frankfurt/Main: Vervuert.

Coole, D. H., \& Frost, S. (Eds.). (2010). New materialisms. Ontology, agency, and politics. Durham: Duke University Press.

D’Ascenzo, A. (Ed.). (2004). Mundus Novus, Amerigo Vespucci e i metodi della ricerca storico-geografica. Roma: Società Geografica Italiana.

da Verrazzano, G. (1970). Transcription of the Cellere Codex. In L. C. Wroth (Ed.), The voyages of Giovanni da Verrazzano 1524-1528 (pp. 123-132). New Haven and London: Yale University Press.

Daston, L. (2002). Die Lust an der Neugier in der frühneuzeitlichen Wissenschaft. In L. Daston \& K. Krüger (Eds.), Curiositas. Welterfahrung und ästhetische Neugierde in Mittelalter und früher Neuzeit (pp. 147-180). Göttingen: Wallstein.

Ecker, G., \& Scholz, S. (Eds.). (2000). Umordnungen der Dinge. Königsstein: Helmer.

Genz, J. \& Gévaudan, P. (2016). Medialität, Materialität, Kodierung. Grundzüge einer allgemeinen Theorie der Medien. Bielefeld: transcript.

Giesecke, M. (1991). Der Buchdruck in der frühen Neuzeit. Eine historische Fallstudie über die Durchsetzung neuer Informations- und Kommunikationstechnologien. Frankfurt/Main: Suhrkamp. 
Giesecke, M. (2006). Die Entdeckung der kommunikativen Welt. Studien zur kulturvergleichenden Mediengeschichte. Frankfurt/Main: Suhrkamp.

Guidi Bruscoli, F. (2014). Bartolomeo Marchionni, 'Homem de grossa Fazenda' (ca. 1450-1530). Un mercante fiorentino a Lisbona a l'impero portoghese. Firenze: Olschki.

Hahn, H. P. (Ed.). (2015). Vom Eigensinn der Dinge. Für eine neue Perspektive auf die Welt des Materiellen. Berlin: Neofelis.

Heijkant, M. J. (2003). Die Darstellung des Reiseberichtes in den Briefen von Amerigo Vespucci an Lorenzo di Pierfrancesco de' Medici. In X. v. Ertzdorff \& G. Giesemann (Eds.), Erkundung und Beschreibung der Welt. Zur Poetik der Reise- und Länderberichte (pp. 289-309). Amsterdam: Rodopi.

Hicks, D., \& Beaudry, M. (Eds.). (2010). The Oxford handbook of material culture studies. Oxford: Oxford University Press.

Kalthoff, H., Cress, T., \& Röhl, T. (Eds.). (2016). Materialität. Herausforderungen für die Sozial- und Kulturwissenschaften. Paderborn: Fink.

Kiening, C. (2002). Ordnung der Fremde. Brasilien und die theoretische Neugierde im 16. Jahrhundert. In L. Daston \& K. Krüger (Eds.), Curiositas. Welterfahrung und ästhetische Neugierde in Mittelalter und früher Neuzeit (pp. 59-109). Göttingen: Wallstein.

Kiening, C. (2007). 'Erfahrung' und 'Vermessung' der Welt in der frühen Neuzeit. In J. Glauser \& C. Kiening (Eds.), Text-Bild-Karte: Kartographie der Vormoderne (pp. 221-251). Freiburg i. Br.: Rombach.

Kleinschmidt, C. (2013). Die Literatur, das Material und die Künste. Intermaterialität aus literaturwissenschaftlicher Perspektive. In T. Strässle, C. Kleinschmidt \& J. Mohs (Eds.), Das Zusammenspiel der Materialien in den Künsten: Theorien-Praktiken-Perspektiven (pp. 69-84). Bielefeld: transcript.

Knoll, M. (2013). Die Natur der menschlichen Welt. Siedlung, Territorium und Umwelt in der historischtopografischen Literatur der frühen Neuzeit. Bielefeld: transcript.

Krüger, K. (2002). Einleitung. In L. Daston \& K. Krüger (Eds.), Curiositas. Welterfahrung und ästhetische Neugierde in Mittelalter und früher Neuzeit (pp. 7-18). Göttingen: Wallstein.

Lange-Berndt, P. (Ed.). (2015). Materiality. Cambridge: The MIT-Press.

Mersch, D. (2002). Was sich zeigt. Materialität, Präsenz, Ereignis. München: Fink.

Mersch, D. (2013). 'Erscheinung des "Un-Scheinbaren"'. Überlegungen zu einer Ästhetik der Materialität'. In T. Strässle, C. Kleinschmidt \& J. Mohs (Eds.), Das Zusammenspiel der Materialien in den Künsten: Theorien-Praktiken-Perspektiven (pp. 27-44). Bielefeld: transcript.

Masini, G., \& Gori, I. (1998). L’America fu concepita a Firenze. Firenze: Bonechi.

Michael, J. (2002). Der Brief als Medium der Entdeckungen: Kolumbus, Caminha und Vespucci und die Figur des Edlen Wilden. In M. Fludernik, P. Haslinger \& S. Kaufmann (Eds), Der Alteritätsdiskurs des Edlen Wilden. Exotismus, Anthropologie und Zivilisationskritik am Beispiel eines europäischen Topos (pp. 65-94). Würzburg: Ergon.

Milanesi, M. (1982). Giovanni Battista Ramusios Sammlung von Reiseberichten des Entdeckungszeitalters. 'Delle Navigazioni e Viaggi' (1550-1559) neu betrachtet. In A. Maczak \& H. J. Teuteberg (Eds.), Reiseberichte als Quellen europäischer Kulturgeschichte: Aufgaben und Möglichkeiten der historischen Reiseforschung (pp. 33-44). Wolfenbüttel: Herzog August Bibliothek.

Miller, D. (Ed.). (2005). Materiality. Durham: Duke University Press.

Mollat Du Jourdin, M. \& Habert, J. (Eds.). (1982). Giovanni et Girolamo Verrazzano, navigateurs de François Ier. Paris: Imprimerie nationale.

Morison, S. E. (1971). The voyages of Verrazzano 1524-1528. In S.E. Morison (Ed.), The European discovery of America: The northern voyages A.D. 500-1600 (pp. 277-325). New York: Oxford University Press.

Obermeier, F. (2003). Die frühen illustrierten Einblattdrucke zu Amerika und ihre Verbreitung im zeitgenössischen Pressewesen. Wolfenbüttler Notizen zur Buchgeschichte, 28, 3-29.

Omodeo, P. (2017). Amerigo Vespucci e l'annuncio del Nuovo Mondo. Roma: Artemide.

Pagden, A. (1993). European encounters with the new world. From Renaissance to Romanticism. New Haven: Yale University Press.

Pinto, G., Rombai, L., \& Tripodi, C. (Eds.). (2014). Vespucci, Firenze e le Americhe. Firenze: Olschki.

Pratt, M. L. (1991). Arts of the contact zone. Profession, 33-40.

Pratt, M. L. (1992). Imperial eyes. Travel writing and transculturation. London: Routledge.

Ramusio, G. B. (1978-1988). Navigazioni e viaggi, 6 vol. Torino: Einaudi.

Reichert, F. (1996). Ludovico de Varthema und sein Itinerar. In L. De Varthema, Reisen im Orient (pp. 7-31). Sigmaringen: Thorbecke. 
Reichert, F. (2000). Von Mekka nach Malakka? Ludovico de Varthema und sein Itinerar (Rom 1510). In X. von Ertzdorff (Ed.), Beschreibung der Welt. Zur Poetik der Reise- und Länderberichte (pp. 273-298). Amsterdam: Rodopi.

Romanini, F. (2007). 'Se fussero più ordinate, e meglio scritte...' Giovanni Battista Ramusio correttore ed editore delle Navigazioni et viaggi. Roma: viella.

Rubiés, J. P. (2000). Travel and ethnology in the Renaissance. South India through European eyes, 12501625. Cambridge: Cambridge University Press.

Samida, S., Eggert, M. K. H., \& Hahn, H. P. (Eds.). (2014). Handbuch Materielle Kultur. Bedeutungen, Konzepte, Disziplinen. Stuttgart: Metzler.

Scholz, S., \& Vedder, U. (Eds.). (2018). Handbuch Literatur \& materielle Kultur. Berlin: De Gruyter.

Schwartz, S. I. (2003). The mismapping of America. Rochester: University of Rochester Press.

Scruzzi, D. (2010). Eine Stadt denkt sich die Welt. Wahrnehmung geographischer Räume und Globalisierung in Venedig von 1490 bis um 1600. Berlin: Akademie Verlag.

Spallanzani, M. (1997). Mercanti fiorentini nell'Asia portoghese (1500-1525). Firenze: Edizioni S.P.E.S.

Spallanzani, M. (1999). Giovanni da Empoli. Un mercante fiorentino nell'Asia portoghese. Firenze: Edizioni S.P.E.S.

Stagl, J. (2002). Eine Geschichte der Neugier. Die Kunst des Reisens 1500-1800. Wien: Böhlau.

Stoll, E. (1997). Konquistadoren als Historiographen. Diskurstraditionelle und textpragmatische Aspekte in Texten von Francisco de Jerez, Diego de Trujillo, Pedro Pizarro and Alonso Borregán, Tübingen: Narr.

Storz, O.-H. (Ed.). (2009). Giovanni Battista Ramusio und seine 'Navigazioni e viaggi'. In Die persische Karte. Venezianisch-persische Beziehungen um 1500. Reiseberichte venezianischer Persienreisender (pp. 5-16). Berlin: LIT.

Strässle, T. (2013). Einleitung-Pluralis materialitatis. In T. Strässle, C. Kleinschmidt \& J. Mohs (Eds.), Das Zusammenspiel der Materialien in den Künsten. Theorien-Praktiken-Perspektiven (pp. 7-23). Bielefeld: transcript.

Strässle, T., Kleinschmidt, C. \& Mohs, J. (Eds.) (2013). Das Zusammenspiel der Materialien in den Künsten: Theorien-Praktiken-Perspektiven. Bielefeld: transcript.

Tarrow, S. (1970). Translation of the Cèllere Codex. In L. C. Wroth (Ed.), The voyages of Giovanni da Verrazzano 1524-1528 (pp. 133-143). New Haven and London: Yale University Press.

Tiller, E. (2013). Giovanni da Verrazzanos Nordamerika-Erkundung für François I. (1524): Variationen des fernen Anderen. In S. Greilich \& K. Struve (Eds.), „Das Andere Schreiben.” Diskursivierungen von Alterität in Texten der Romania (16.-19. Jahrhundert), (pp. 17-32). Würzburg: Königshausen \& Neumann.

Tilley, C., Keane, W., Küchler, S., Rowlands, M., \& Spyer, P. (Eds.). (2006). Handbook of material culture. London: Sage.

Todorov, T. (1982). La conquête del l'Amérique. La question de l'autre. Paris: Seuil.

Vespucci, A. (1916). Mundus Novus. Letter to Lorenzo Pietro di Medici (Trans., G. T. Northup), In Vespucci Reprints, Texts and Studies. The Mundus Novus in Translation, Princeton: Princeton Univ. Pr.

Waldenfels, B. (1997). Topographie des Fremden. Studien zur Phänomenologie des Fremden I. Frankfurt/ Main: Suhrkamp.

Waldenfels, B. (2006). Grundmotive einer Phänomenologie des Fremden. Frankfurt/Main: Suhrkamp.

Wallisch, R. (2002). Der Mundus Novus des Amerigo Vespucci. Text, Übersetzung und Kommentar. Wien: Verlag der Österreichischen Akademie der Wissenschaften.

Wroth, L. C. (1970). The voyages of Giovanni da Verrazzano 1524-1528. New Haven and London: Yale University Press.

Publisher's Note Springer Nature remains neutral with regard to jurisdictional claims in published maps and institutional affiliations. 